\title{
Indonesian Migrant Domestic Workers and Sustainable Development Goals: Feasible Policy and Practices
}

\author{
Anggia Utami Dewi ${ }^{1, *}$, Teuku Rezasyah ${ }^{2}$ \\ ${ }^{1}$ International Relations Department, Universitas Padjajaran, J1. Raya Bandung Sumedang KM.21, Hegarmanah, \\ Jatinangor, Kabupaten Sumedang, Jawa Barat 45363, Indonesia
}

\begin{abstract}
The issue of Indonesian migrant domestic workers is still a homework that need to be prioritized by the government. The problematic management, include the lack of legal-based protection, have resulted in many unfortunate cases and conditions of migrant workers. Many of them are prone to unequal treatments, mental and physical abuse, even human trafficking. The Indonesian government currently addresses a policy of zero migrant worker roadmap, which has brought up many critics mentioning how the policy is discriminatory and violates the rights to economy of the workers. By using a qualitative approach of method, this paper aims to discuss the possibility of solutions that will generate an inclusive framework of to eradicate inequalities posed by Indonesian migrant domestic workers, by briefly highlighting the case of Sumba Barat Daya as the second largest migrant workers sender in Nusa Tenggara Timur. Under the Sustainable Development Goals framework, from policy approach, this paper suggests the government of Indonesia to focus more on the skill and capacity building of migrant workers, by also imposing the social protection approach towards them.
\end{abstract}

\section{Keywords: Indonesia's Migrant Domestic Workers, Inclusive Policy, Sustainable Development Goals}

\section{Introduction}

By the year of 2016, global assessment shows that domestic workers count as one of the most expanding sector in informal employment, where predicted more than 67 million domestic workers, dominantly women, are engaged in a work performed in or for a household or households [1]. Within the total number of domestic workers worldwide, around 17.2 per cent or 11.5 million of them are migrant domestic workers. Domestic work plays a quiet important role for the labor economy, even for Latin American and Asian regions, domestic work contributes by 14 percent and 11 percent of female wage employment. Despite of these facts, the discourse of domestic workers especially migrant domestic workers are negatively highlighted due to many problematic issues regarding the 'dirty, dangerous, demeaning' image, low wages, poor working conditions, and low legal-based protection and management from national government. It could be implied that migrant domestic worker environment has been bad. It shows that good environment of migrant worker all this time hasn't become priority yet. These have further resulted in many abusive cases, work-related incidents of migrant domestic workers, even human trafficking.

Indonesia, as one of the major sending countries of migrant domestic workers in Asia is also facing the unfinished problems regarding the management and protection of migrant domestic workers. Started from the Susilo Bambang Yudhiyono leadership, the current Joko Widodo's administration has implemented the zero migrant workers roadmap, in order to avoid the cases of mental and physical abuses, unequal treatments and poor working conditions because of inadequate legal protection for Indonesian domestic workers abroad. President Widodo clearly stated that to stop sending migrant domestic workers is rationale to protect the 'dignity' of Indonesia [2]. The Indonesian Minister of

* Corresponding author e-mail anggia.utami@unpad.ac.id 
Manpower, Hanif Dakhiri, explained that the zero migrant workers policy refers to the combination of hard and soft policies, which pinpointed to the ban of "informal" migrant domestic workers to the Middle East since 2015, and the negotiation with the recipient countries of domestic migrant workers regarding the transformation from unskilled to professional status of migrant domestic workers. However, this ban policy has triggered critics mentioning that the policy is a discriminatory and violates the economy rights of the workers [1][2]. Economists also predict that this policy will give a downfall for Indonesian economy, since the economic contribution from remittances of Indonesian migrant workers are bigger than the number of foreign direct investment or official development assistance [3].

On the other hand, under the Sustainable Development Goals agenda, the decent work and sustained economic growth counted as one important goal, which includes the migrant domestic worker within it. This means, instead of banning the placement of migrant domestic workers, activists and international organizations suggest that the reform of the management and protectionist approach should be implemented, to ensure that all people get full access for decent work.

\section{Methodology}

Through a qualitative approach of method, this paper elaborates the discussion on the possible solutions will generate an inclusive framework of to eradicate inequalities posed by Indonesian domestic migrant workers, by also highlighting briefly on Sumba Barat Daya as the second largest migrant workers sender in Nusa Tenggara Timur.

\section{Discussion}

Sumba Barat Daya (South West Sumba, hereafter $\mathrm{SBD}$ ) is one of the outer islands in Indonesia, where development growth in the region is still regarded as low, with the number of people living in poverty is around 20 per cent[4]. The high rate of unemployment and minimum employment opportunity have made many population from Sumba Barat Daya find the opportunity to work outside their hometown or even home country. Therefore, SBD become the second largest migrant workers sending region in Nusa Tenggara Timur (East Nusa Tenggara, henceforward
NTT) and one of the Indonesian migrant workers' base, with the main migrant workers destination country from this region is Malaysia[5]. Most of the migrant workers are women who are employed under the domestic work scheme. They contribute as the economic engine for the daily lives of their families from the remittances they send back home. However, the most appealing problem in this region is the human trafficking issue. The NTT Province where SBD located still hold the highest national rank on human trafficking cases, dominantly occur to women and young girls who aims to work as domestic workers[6]. Due to many cases of human trafficking, the number of migrant domestic workers from Sumba Barat Daya has drastically decreased. According to the data on March 2017, there were only 81 migrant workers departed to destination country since early 2017, and only total 243 migrant workers left to Malaysia and Singapore during 2016[7].

Seeing the significance of migrant domestic workers whom dominantly women to the economic development of the SBD region, it is crucial to address that banning them from going abroad will poses more harms. First, by 'closing' or 'limiting' the deployment through legal path, the possibility of people whom trapped or choose voluntarily to go by the 'illegal' path will be higher. Second, without a comprehensive system provided to boost up the local economy, the unemployment rate and the poverty level will increase undoubtedly. Third, it is important to also mark that the push factors of women migrant domestic workers in SBD are not only economic reason, but also sociocultural rationales. They choose to 'escape' from the pressure to enter the force marriage in young age by working outside their hometown. Instead of closing their way to pursue a better life, more options should be provided so they can decide the choices available for them.

There has been many attentions given to address the issue of migrant domestic workers worldwide. Practitioners, activists, international organizations, NGOs, national governments and other stakeholders realize that one of the main problems of the migrant domestic workers' issue lies on the absence of specific regulation of international labor standard for domestic workers before the adoption of Domestic Workers Convention No. 189 and Recommendation No. 201 on 2011 from International Labor Organization (ILO). Therefore these instruments try to fill the legal and policy gaps by giving the basic principles and minimum labor standards for domestic work, by also considering the 
dynamics of circumstance on the nature of the work itself, as well on the national level arrangement[8]. These instruments are also proving how ILO try to actuating the decent work agenda that applicable for domestic workers. As Albin and Mantouvalou delivered in their paper, the Convention states clearly that Members shall take measures to ensure that domestic workers, like other workers generally, enjoy fair terms of employment as well as decent working conditions[9].

To realizing the purpose of the adoption of the Convention which is decent work for all (women migrant) domestic workers, ILO has been working on four core strategies: promotion of the ratification and implementation of the new instruments (convention and recommendation); provision of assistance in building institutional capacity and supporting policy and legislative reforms at national level; facilitation of the organization and representation of domestic workers and their employers; and lastly effort on advocacy and to raise the awareness[10]. Under the institutional capacity, the empowerment of domestic workers which dominantly are women is also addressed. These two frameworks, decent work and women empowerment to achieve gender equality are mentioned as two of the goals aimed to be achieved for the inclusive development under the Sustainable Development Agendas (SDGs).

In ASEAN, Philippines is one of the member states that ratified and implemented the Convention on Domestic Workers into national regulation. The Batas Kasambahay Bill was signed into law on 2013, providing the labor and social protections to mainly local domestic workers in the Philippines, but also presents for Filipino migrant domestic workers in the terms of fair working and living conditions under the employment contracts[11]. On the framework of migrant workers empowerment, Philippines also constitutes as one of the best practices for country that has a much better management of migrant workers, especially the domestic workers. Capacity building is fully prepared from the pre-departure training that has a comprehensive curriculum inducing the intercultural competence as one crucial skill needed for domestic workers. To be more precise, the intercultural competence includes the language proficiency that will be lift up the bargaining position of migrant domestic workers. It will help reducing barriers and ease the communication between employers and workers, and also will give advantage and benefits point for advocacy or legal protection when problems occurred.

In the case of Indonesia in general, and SBD specifically, the framework of decent work for migrant domestic workers that has the protectionist and human rights approach has not been presence in the labor law or regulations. Migrant Care, a prominent nongovernmental organization for migrant workers in Indonesia, argued that the current policy products that govern the migrant workers in Indonesia has more exploitative dimension that protective dimension. They further stated that the current migration law and the zero migrant policy show the inadequacy of Indonesian government to care for the reality of vulnerability and potential for human rights violation faced by Indonesian migrant workers, especially woman domestic workers. It also indirectly pictures the discrimination from the government by dichotomizing migrant workers into formal-informal, skilled-unskilled, legal-illegal, which will affect the treatment towards those workers. As for the migrant workers empowerment, Indonesia still also has a long way to go, especially because the current predeparture training system for migrant domestic workers seem lacking of comprehensive approach to prepare the fully-competence workers. The period of training is too short, and the curriculum is too simple. However, appreciation should be given in the terms how administratively, current Indonesian government has established several "one stop services" points for Indonesian migrant workers in regions with high number of migrant workers, including in SBD[12]. The purpose is to prevent the routes to human trafficking as well undocumented migrations of workers.

\section{Conclusion}

From the discussion above, several points of conclusion can be highlighted. First, that regardless the aims to send only professional workers abroad, the Indonesian government zero migrant policy poses discrimination towards the rights of migrant workers for to economy. Second, one possible approach to handle the Indonesian migrant domestic workers issue is by integrating the decent work and migrant workers empowerment frameworks to the inclusive development agenda through the comprehensive reformation on law also regulations instruments within national boundaries. Third, the approach of migration policies on migrant workers should be focusing on protecting the lawful rights of all migrant workers, not just on the placement procedures. Taking the best practices from other countries such as Philippines will be advantageous example of how to integrate the international norms of domestic workers protection into national policy and finally operationalizing those norms into real actions. 


\section{References and Notes}

1. International Labour Organization. "Formalizing Domestic Work", International Labour Office, Geneva (2016)

2. "Jokowi Minta Penghentian Pengiriman TKI Dikaji, BNP2TKI Siapkan Langkah”, Detik News, February 15, 2015. Retrieved from https://news.detik.com/berita/2833683/jokowiminta-penghentian-pengiriman-tki-dikaji-bnp2tkisiapkan-langkah

3. N. Varia. "Indonesia: Banning Migrant Domestic Work is Short-Sighted". Human Rights Watch, February 17, 2015. Retrieved from https://www.hrw.org/news/2015/02/17/indonesiabanning-migrant-domestic-work-short-sighted

4. H. Jacques. "Widodo ban on Middle East placements could hurt Indonesian economy". Asian Review, July 23, 2015. Retrieved from https://asia.nikkei.com/Politics-Economy/PolicyPolitics/Widodo-ban-on-Middle-East-

placements-could-hurt-Indonesianeconomy?page $=2$

5. M. Kwong, P. Ronas. "Dinamika Pekerjaan, Pasar Tenaga Kerja serta Perekonomian di Nusa Tenggara Timur", Organisasi Buruh Internasional, p.15-16, (2011).

6. S. Kelilaw. "Sumba Barat Daya, Lumbung Penyuplai TKI Nomor Dua di NTT". Tabloid Flobamora Dewata, July 16, 2016. Retrieved from http://flobamoradewata.com/2016/07/16/sumbabarat-daya-lumbung-penyuplai-tki-nomor-dua$\underline{\mathrm{ntt}-2 /}$
7. A. Rianghepat. "NTT Tertinggi soal Kasus TKI Ilegal, Menteri Yohana Minta Pemda Tekan Pengiriman TKI". Okezone News, May 4, 2017. Retrieved from https://news.okezone.com/read/2017/05/04/340/ 1683518/ntt-tertinggi-soal-kasus-tki-ilegalmenteri-yohana-minta-pemda-tekanpengiriman-tki

8. “TKI SBD Menurun Drastis". Timor Express, March 25, 2017. Retrieved from http://timorexpress.fajar.co.id/2017/03/25/tkisbd-menurun-drastis/

9. ILO. "ILO Strategy for Action Towards Making Decent Work a Reality For Domestic Workers Worldwide", Geneva: International Labour Office, (2012).

10 Albin, Einat and Mantouvalou, Virgina. "The ILO Convention on Domestic Workers: from the Shadows to the Light" in Industrial Law Journal, p. 7 (2012).

11. ILO. "ILO Strategy for Action Towards Making Decent Work a Reality For Domestic Workers Worldwide", Geneva: International Labour Office, (2012).

11. J. D'Cunha, and N. Lewis, "Domestic Workers Count Too: Implementing Protections for Domestic Workers", New York: UN Women Headquarters, p. 27, (2013).

12. Heriyanto. "Dukungan Bagi Layanan Terpadu Satu Atap TKI Sangat Diperlukan”. Berita Satu, April 10, 2017. Retrieved from http://www.beritasatu.com/ekonomi/424225dukungan-bagi-layanan-terpadu-satu-atap-tkisangat-diperlukan.html 